\title{
INDICATOR ANALYSIS OF SMART CITY STANDARD SNI ISO 37122 PLAYS A ROLE IN THE COVID-19 PANDEMIC
}

\author{
B. D. Tampubolon ${ }^{1,3}{ }^{*}$, A. B. Mulyono ${ }^{1}$, F. Isharyadi ${ }^{1}$, E. H. Purwanto ${ }^{1}$, W. C. Anggundari ${ }^{1}$, Gensly $^{2}$ \\ ${ }^{1}$ Center of Research and Human Resources Development National Standardization Agency of Indonesia, South Tangerang, \\ Indonesia - (dulbert, arybudi, febrian, endi, widiacitra)@bsn.go.id \\ ${ }^{3}$ Chair of Innovation Economics, Technische Universität Berlin, Straße des 17. Juni 135 D-10623 Berlin \\ ${ }^{2}$ Directorate of Regions, Cities and State Boundaries Ministry of Home Affairs, Jakarta, Indonesia - gensly_66@yahoo.com
}

KEY WORDS: Smart City Standard, Indicator, Pandemic, Cause and Effect.

\begin{abstract}
:
A smart city is a city development concept based on the principles of information technology so that the management of all resources runs effectively and efficiently. One of the concepts of implementing smart cities that have been developed is through the application of the SNI ISO 37122: 2019 standard. During the Covid-19 pandemic, the smart city concept is expected to play a role in increasing the effectiveness of implementing health protocols in urban environments. The purpose of this preliminary research is to analyze smart city indicators in the SNI ISO 37122 standard which are directly related to preventing the spread of the Covid-19 Pandemic. This research uses descriptive qualitative methods and literature study. To link the smart city indicator and the Covid-19 pandemic health protocol, the Cause-and-Effect Analysis (CEA) method and brainstorming using expert judgment were used. Based on the results of the analysis of 19 sectors contained in the standard, there are 11 sectors and 21 indicators that have roles in limiting the spread of the Covid-19 pandemic in Indonesia.
\end{abstract}

\section{INTRODUCTION}

The development of cities using the smart city concept has been going on for more than the last decade. The concept of smart city has been developed by developed countries particularly by their standard development organizations such as the United States (NIST, ANSI, and ACR NEMA), UK (BSI), China (NITS), Germany (DKE and DIN), and Korea. In addition, regional and international organizations have worked and contributed greatly to the smart city standards development and other supporting components such as ITU-T, IEC, IEEE Standards Association, European Commission, CEN CENELEC, and ETSI, and ISO. During the pandemic era, smart city standards application is expected to have more roles in overcoming problems that arise in society and urban environment, in particular limiting the spread of viruses, such as Covid-19. A number of smart city standards and its concept are available can to support Local / Municipal Governments in its implementation, however it also creates some confusions. For this reason, researchers need to analyze smart city indicators using the ISO Sustainable cities and communities' standards which are directly related to preventing the spread of the Covid19 pandemic. Various sectors in the ISO standard need to be analyzed based on their role in inhibiting the spread of Covid19. The analysis will be carried out through assessments by experts from various relevant stakeholders. Once the sectors that play roles in inhibiting the spread of Covid-19 were identified, further analysis was conducted to determine indicators that have direct role. This is needed to see the role of ISO standards in solving current problems. Based on this, in the future, smart city development policy will experience an increase in dealing with Covid-19 and to face challenges of other problems that might occur in the future (Kunzmann, 2020).

\section{LITERATURE REVIEW}

\subsection{Smart City Policy in Indonesia}

Indonesia has established a Master Plan on Smart City Development Program which aims at accelerating the potential and competitiveness of each region/city, and to improve community services based on local wisdom and by maximizing the application of technology. Currently, there are 514 districts/cities plus special cities in Indonesia that have been determined to be potential for the development of the smart city concept. The government and stakeholders must work together to realize this Smart City, following Government Regulation No. 28 of 2018 concerning Regional Cooperation through Smart Economy, Smart People, Smart Government, Smart Mobility, Smart Environment and Improved Quality of Life Smart Living. Related parties must integrate all of these aspects when they provide services to the community in such an effective and efficient way. Smart City development includes the construction of basic infrastructure, transportation systems, energy-efficient buildings, and environmentally friendly waste management. The challenge in the future for implementing smart cities is how the concept of a smart city can be applied to small cities which are important to encourage the welfare of the people in the city area (Abusaada \& Elshater, 2020).

The smart city is one of the innovation programs that are intensively developed in Indonesia by adopting information technology in city management (Syahbudin, 2016). However, some of these programs adopt the concept of the Internet of Things through the implementation of five main components, namely environmental monitoring, smart parking, mobile environmental monitoring, traffic monitoring, and park and garden irrigation. In previous studies, there were four main obstacles in achieving the application of smart cities in general. Firstly, the absence of an umbrella regulation covering smart city development programs. Secondly, there are not enough IT- 
based human resources to operate the smart city program. Thirdly, is limited access to budgets related to smart city development. Lastly, active role is required from private sectors, academia, and communities in forming an integrated and sustainable smart city ecosystem (Kurnadi, 2015).

\subsection{Pandemic and its problems}

The Covid-19 pandemic has not only caused health problems but has disrupted the entire structure of people's lives and created social, cultural, and economic problems. The pandemic has almost paralyzed the socio-economic conditions of people in Indonesia, especially in some areas with the highest rates of spread, such as Jakarta, Bogor, Depok, Tangerang, and Bekasi. During this pandemic, the Government has imposed social restrictions on small, medium and large-scale enterprises to prevent and control the spread of Covid-19. The socioeconomic problems caused by Covid-19 are increasingly visible to the community. Some of the socio-economic problems that have occurred due to Covid-19 include scarcity of goods, social disorganization and dysfunction, criminal acts, weakening of the tourism sector, and an increase in poverty and unemployment. A study states that two methods can be applied by the Government to society, namely: 1) How to carry out social restrictions without reducing people's freedom, instead the Government and society can supervise and be supervised with the help of technology and 2) How to impose lock down policy or flexible social restrictions based on health status of the areas which is updated all the time and can be accessed online (Sonn, Kang, \& Choi, 2020).

The condition of the Covid-19 pandemic is one of the real challenges that must be faced by regional and city governments. The Government has established some policies related to handling of the Pandemic and Health Protocols to address the problems that arise. In the context of preventing and controlling the coronavirus, the Government established the $3 \mathrm{M}$ Health Protocol for communities in public places and facilities based on the Decree of the Minister of Health of the Republic of Indonesia Number HK.01.07 / MENKES / 382/2020. The 3M protocol is very simple, covering wearing masks, washing hands, and keeping your distance. To support the implementation of health protocols, the Government emphasizes the massive implementation of the 3T (Testing, Tracing, Treatment) Policy to be the Guidelines, Prevention and Control of Covid-19 which is based on the Minister of Health Regulation Number HK.01.07 / Menkes / 413/2020. The 3M and $3 \mathrm{~T}$ programs cannot be separated and are a package in breaking the chain of transmission of the Coronavirus pandemic. This program is also integrated with the program of providing business incentives for MSMEs by the Committee for Handling COVID-19 and National Economic Recovery (KPCPEN). In addition, the Ministry of Religious Affairs issued Instruction Number 1 of 2021 concerning the Socialization Movement for the Implementation of the 5M Health Protocol, namely wearing masks, washing hands with soap and running water, maintaining distance, staying away from crowds, and limiting mobilization and interaction. This policy is expected to be able to overcome the increasing number of Coronavirus patients in Indonesia and its spreading out.

In addition, the Indonesian government has also issued a social distancing appeal policy, an appeal for Work from Home for employees, imposing regional restrictions, building a special hospital for handling Covid-19, and others. The World Health Organization (WHO) changed the term social distancing to physical distancing. The change in this term is intended so that interactions between people are still possible but they are physically far apart.

\subsection{Smart City Standard}

Sustainable development of international standards takes into account the current environmental, social, and economic needs without sacrificing the opportunities for future generations to access resources. Many international and national standards bodies are working to develop Smart City standards. However, the complexity of handling the smart city system is unlikely to be covered by some standards. Collaboration from different stakeholders from cities and standards bodies is very useful to create a general model of the city and its systems. So that the needs of the city to manage problems are met in a connected system such as privacy, security, resilience, data flow, and so on, including the evaluation of the use of ICT in realizing a smart city. For example, the need for interoperability between different city systems is needed to understand the many complexes and interrelated ICT problems associated with moving towards smarter cities. So that fulfilling the requirements of the city show smarter progress. In particular, the relevant standards become measurable.

ISO (International Organization for Standardization) has established a technical committee related to sustainable cities and communities i.e., ISO / TC Code 268. This technical committee handles standardization in the field of Sustainable Cities and Communities which will cover the development of requirements, frameworks, guidelines, and supporting techniques and tools related to achieving sustainable development by considering intelligence and resilience, to help all Cities and Communities and their stakeholders both in rural and urban areas become more sustainable. The standardization activities in TC 268 contribute to the United Nations Sustainable Development Goals, encouraging the development and application of a holistic and integrated approach to sustainable development and sustainability. The smart city standard describes and establishes the definition and methodology for a set of indicators to direct and measure smart city service performance and quality of life. It follows the principles set out in the standard and seeks to measure its performance in a comparable and verifiable way, regardless of size and location. In addition, it also explains activities relevant to smart community infrastructure such as energy, water, transportation, waste, and information and communication technology (ICT). So that the concept of intelligence is aimed at performance relevant to solutions that can be applied technologically, following sustainable development and community resilience. Smart city standards can be applied to one type or different types of community infrastructure, and involve all levels of society. Among the importance of the concept of a smart city for waste management is that the pandemic has become a catalyst for accelerating the application of smart cities due to the need for medical waste management in handling Covid-19 (Onoda, 2020).

The standards developed by the technical committee and subcommittee for city and community sustainability are as follows:

1) ISO 37101 Sustainable development in communities management system for sustainable development requirements with guidance for use,

2) ISO 37120 Sustainable cities and communities - indicators for city services and quality of life,

3) ISO 37122 Sustainable cities and communities - Indicators for smart cities,

4) ISO/TR 37150 Smart community infrastructures - review of existing activities relevant to metrics, 
5) ISO 37151 Smart community infrastructures — principles and requirements for performance metrics,

6) ISO 37153 Smart community infrastructures — maturity model for assessment and improvement.

\subsection{The Concept of Smart City Nowadays}

The concept of smart city including its definitions is still very diverse (Syahbudin, 2016). Currently, the concept of the smart city still only focuses on public services using technology to accelerate regional / city development. The concept of smart city must be able to overcome obstacles/problems by using technology in the activities of public organizations to provide effective, efficient, and quality public services to develop local economy (Dawes, 2008; Cohen, 2012). According to Nijkamp (2008) and Plimbi (2014), natural resource management and government participation are parts of smart city concept. According to Utomo \& Hariadi(2016), this concept includes the provision of easy and fast information services for the public by using technology applications. It is expected that community problems can be resolved appropriately and provide a sense of comfort, security, and order. In addition, the concept of the smart city refers to three main elements, namely humans, technology, and institutions (Nurmandi, 2006). So, smart city is a city concept that has integrated connections in various fields by providing practical impact and efficiency in city management.

According to Awaluddin (2016), a smart city has nine main parameters based on category, namely Smart Energy; Smart Building; Smart Mobility; Smart Technology; Smart Infrastructure; Smart Governance; Smart Healthcare; Smart Citizen; and Smart Security. According to Goldsmith \& Crawford (2014), the smart city concept is an attempt by local governments to use new technology to link breakthroughs in the use of big data analytics and collaboration between government and citizens. In developed countries, government services have involved the community, and open data is used for the development of city government policies. Urban planning revolution, using digital technology is applied to plan sustainable environmental design. Another smart city concept, put forward by Giffinger et al (2007) has six dimensions, namely smart government, smart environment, smart people, smart economy, smart living, and smart mobility . The most important thing in handling Covid-19 is how to find individual and social responses to Covid-19. This is what is called community psychological data and this is important to build (James et al., 2020).

So the most important concept is that even though it uses a lot of technology and innovation, it is still necessary to create a system that can significantly build efficient smart cities that support better responses to save lives during this pandemic (Costa et al., 2020).

\section{METHODS}

Figure 1 shows the result of a preliminary study. This needs to be followed by further research to find the bottlenecks in the process of overcoming the spread of the Covid-19 pandemic and identifying indicators and sectors that have no role in supporting health protocols and the reasons of why the process is not working well. The last stage is to correlate indicators of smart city and the development of the number of Covid-19 patients in every effort to limit community activities. This approach is designed to reveal a significant relationship between the two factors.

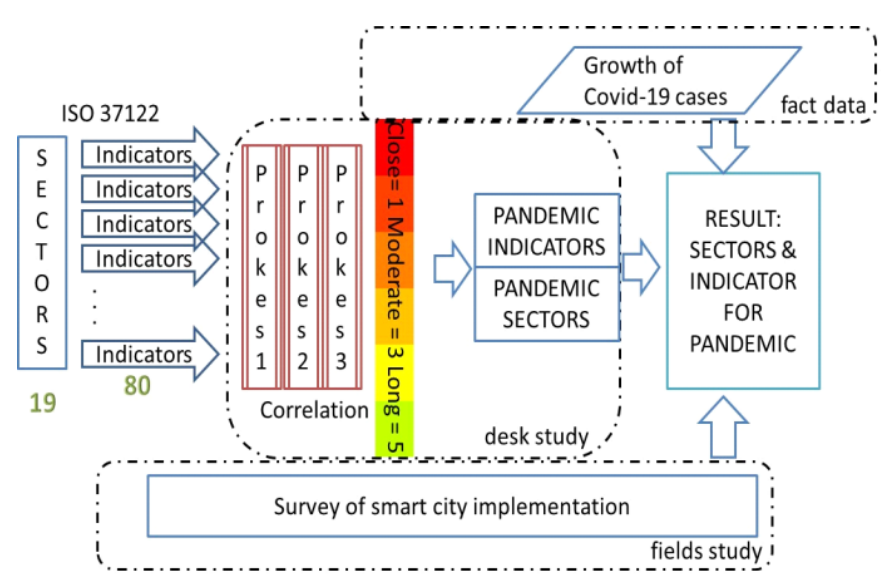

Figure 1. Overall research design

This research uses qualitative descriptive methods and literature study with Cause-and-Effect Analysis (CEA) and brainstorming with expert judgment to connect smart city indicators and health protocols in the face of Covid-19 pandemic. The CEA technique is often called a fishbone diagram or Ishikawa diagram, named after its inventor, Kaoru Ishikawa. It is a tool used to help mapping the causal factors of risk. This technique is often combined with brainstorming techniques to consider causal relationships, which would be the best if it involves those who understand them or experts. A pandemic is a risk or a result of not implementing health protocols and ISO 37122 indicators which play a role in the effective implementation of health protocols in urban environments. Although cause-and-effect analysis is still a potential method, these indicators can also be used as a control to prevent the high risk of coronavirus patients grows before it occurs in the future.

Each stakeholder group such as local government, academia, The Ministry of Home Affairs, and citizens is invited to assess those sectors listed in SNI ISO 37122. The 19 sectors that were assessed include economy, education, energy, environment and climate change, finance governance, health, housing, population and social condition, recreation, safety, solid waste, sport and culture, telecommunication, transportation, urban/local agriculture and food security, urban planning, wastewater, and water. Each stakeholder gave score 0 (no role) or 1 (play a role) through the focus group discussion (FGD). Sectors with score 0,5 or above are sectors that can play a role in preventing the spread of the Covid-19 pandemic.

\section{RESULT AND DISCUSSION}

Smart city is not easy, and hence, it requires strategic and creative thinking. This strategic program begins with problem identification, problem grouping, process abstraction, determination of ways and solutions to problems, and planning for its implementation (Nugraha, 2014). Creativity produces work that is useful and new to be introduced to society and organizations (Lazuardi, 2015). Organizational characteristics can be studied through aspects such as leadership planning and human resources management (HRM) a (Enceng \& Hidayat, 2016). Innovation is one of the strategies that can be taken to improve the performance of public service organizations (Boyne, R. \& Tom, 2010). Although various obstacles were found in its application, it did not stop the steps to continue to make improvements to various applications and various other innovations (Mujiyono, Angkasa, \& Rismawati, 2016). 
Determination of sectors in SNI ISO 37122 that can play a role in inhibiting the spread of the Covid-19 pandemic, follows the pattern of preparing national standards by involving stakeholders. Each stakeholder group is invited to assess these sectors, such as local government (as implementing agencies)), universities (as experts), Ministry of Home Affairs (as regulator), and citizens (as users or consumers). Figure 2 show selected sectors based on FGD by stakeholders that play a role in inhibiting the spread of the pandemic.

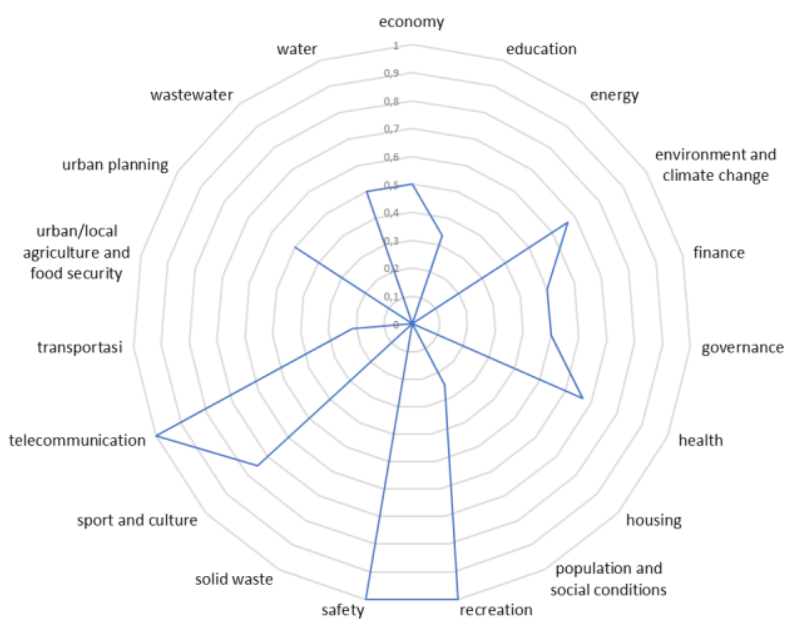

Figure 2. Sectors that can play a role in inhibiting the spread of the pandemic by expert judgement

Based on the analysis, it was found that 11 sectors from 19 sectors on SNI ISO 37122 have roles in limiting the spread of the pandemic. Considering that this is still preliminary research, verification will be needed with the growth rate of Covid-19 patients for each region that has implemented indicators in the selected sector. Based on these preliminary results, it is found that indicators that are considered to play roles in limiting the spread of the pandemic are shown in the following table.

\begin{tabular}{|lll|}
\hline No. sector & Sector title & $\begin{array}{l}\text { Number of } \\
\text { indicators }\end{array}$ \\
\hline 1 & Economy & 2 \\
4 & Environment And Climate & 2 \\
5 & Change & 1 \\
6 & Finance & 2 \\
7 & Governance & 2 \\
10 & Health & 1 \\
11 & Recreation & 1 \\
13 & Safety & 3 \\
14 & Sport And Culture & 3 \\
17 & Telecommunication & 2 \\
19 & Urban Planning & 2 \\
\hline Total & Water & 21 \\
\hline
\end{tabular}

Table 1. The number of indicators per selected sector

Sector determination is determined by the score value for each sector. The score is equal to or more than 0.5 to become the selected sector. In addition to the 21 indicators above, there are
5 other indicators in 3 unselected sectors, namely the transportation sector ( 3 indicators), education (1 indicator), and population and social conditions (1 indicator). So, the SNI ISO 37122 indicators that play roles in limiting the spread of the Covid-19 Pandemic in Indonesia are 21 indicators, as shown in the following table.

\begin{tabular}{|c|c|c|}
\hline No. & Indicator title & $\begin{array}{l}\text { Code. } \\
\text { sector }\end{array}$ \\
\hline 1. & $\begin{array}{l}\text { Service contracts providing city services } \\
\text { which contain an open data policy }\end{array}$ & 1.1 \\
\hline 2. & $\begin{array}{l}\text { The labour force employed in } \\
\text { occupations in the information and } \\
\text { communications technology (ICT) sector }\end{array}$ & 1.3 \\
\hline 3. & $\begin{array}{l}\text { Number of real-time remote air quality } \\
\text { monitoring stations per square kilometre }\end{array}$ & 4.2 \\
\hline 4. & $\begin{array}{l}\text { Public buildings equipped for monitoring } \\
\text { indoor air quality }\end{array}$ & 4.3 \\
\hline 5. & $\begin{array}{l}\text { Payments to the city that are paid } \\
\text { electronically based on electronic } \\
\text { invoices }\end{array}$ & 5.2 \\
\hline 6. & $\begin{array}{l}\text { Annual number of online visits to the } \\
\text { municipal open data portal per } 100000 \\
\text { population }\end{array}$ & 6.1 \\
\hline 7. & $\begin{array}{l}\text { City services accessible and that can be } \\
\text { requested online }\end{array}$ & 6.2 \\
\hline 8. & $\begin{array}{l}\text { The city's population with an online } \\
\text { unified health file accessible to } \\
\text { health care providers }\end{array}$ & 7.1 \\
\hline 9. & $\begin{array}{l}\text { Annual number of medical appointments } \\
\text { conducted remotely per100 } 000 \\
\text { population }\end{array}$ & 7.2 \\
\hline 10. & $\begin{array}{l}\text { Public recreation services that can be } \\
\text { booked online }\end{array}$ & 10.1 \\
\hline 11. & $\begin{array}{l}\text { The city area covered by digital } \\
\text { surveillance cameras }\end{array}$ & 11.1 \\
\hline 12. & $\begin{array}{l}\text { Number of online bookings for cultural } \\
\text { facilities per } 100000 \text { population }\end{array}$ & 13.1 \\
\hline 13. & $\begin{array}{l}\text { The city's cultural records that have been } \\
\text { digitised }\end{array}$ & 13.2 \\
\hline 14. & $\begin{array}{l}\text { Number of public library book and e- } \\
\text { book titles per } 100000 \text { population }\end{array}$ & 13.3 \\
\hline 15. & $\begin{array}{l}\text { The city population with access to } \\
\text { sufficiently fast broadband }\end{array}$ & 14.1 \\
\hline 16. & $\begin{array}{l}\text { City area under a white zone/dead } \\
\text { spot/not covered by telecommunication } \\
\text { connectivity }\end{array}$ & 14.2 \\
\hline 17. & $\begin{array}{l}\text { The city area covered by municipally } \\
\text { provided Internet connectivity }\end{array}$ & 14.3 \\
\hline 18. & $\begin{array}{l}\text { Building permits submitted through an } \\
\text { electronic submission system }\end{array}$ & 17.2 \\
\hline 19. & $\begin{array}{l}\text { The city population living in medium-to- } \\
\text { high population densities }\end{array}$ & 17.4 \\
\hline 20. & $\begin{array}{l}\text { The city's water distribution network } \\
\text { monitored by a smart water }\end{array}$ & 19.3 \\
\hline 21. & $\begin{array}{l}\text { Buildings in the city with smart water } \\
\text { meters }\end{array}$ & 19.4 \\
\hline
\end{tabular}

Table 2. List of selected indicator titles

Various sectors were affected by the impact of this pandemic and various strategies were implemented to minimize the spread of the pandemic impact. The smart city concept is expected to limit its spread and reduce the impact caused by the Covid-19 pandemic. An adaptive and anticipatory smart city arrangement is needed. Pandemic resilient cities can also be designed based on the principles of pandemic management without limiting people's needs for various services. Several things related to the 
challenges of smart city planning during this pandemic are limited activities, environmental conditions, facilities and infrastructure that support a healthy lifestyle, strengthening informatics systems that support various activities to keep them running, as well as a good disaster-resilient mitigation system that must be owned by the city. Among the most important things in maintaining economic sustainability in this pandemic is the role of working remotely which is considered effective (Kylili et al., 2020).

Based on the research results, 11 sectors in the ISO 37122 standard that played a role in the pandemic were:

\section{1) Economic}

- Percentage of service contracts providing municipal services that contain an open data policy. Focus on an open data policy in various city services such as public services, public safety, roads and traffic, fire fighting, and other services.

- Percentage of the workforce working in the Information and Communication Technology (ICT) Sector. Data on the percentage of workers in the ICT sector according to the International Labor Organization (ILO)

2) Environment and Climate Change

- Number of real-time remote air quality monitoring stations per square kilometer $\left(\mathrm{km}^{2}\right)$. Remote real-time air monitoring systems can help assess the impact of climate change on the environment (e.g. air quality).

- Percentage of public buildings equipped to monitor indoor air quality. Monitoring indoor air quality is very important because it can affect the health, comfort, and productivity of the occupants of the room. Indoor air quality monitoring should include primary pollutants (CO, Benzene, formaldehyde, radon, asbestos, Acetaldehyde, Toluene, Ethylbenzene, Xylenes).

3) Finance

Percentage of payments to cities that are paid electronically based on electronic invoices. Electronic payments are payments made via electronic media without using cash or checks. Its use can increase security. The high percentage of e-payments is an indication that the city is very digital.

4) Government

- An annual number of online visits to city open data portals per 100,000 inhabitants. An open data portal provides a means to improve public access to data managed by cities and the data should refer to structured data. The visit will refer to individual visitors arriving at the city's open data portal online and starting to browse and peruse the open data portals.

- Percentage of city services that are accessible and that can be requested online. The ease of accessing city services online can provide benefits for citizens and local governments. The use of mobile technology, such as geotagging and photos can also help the efficiency and effectiveness of city services.

5) Health

- Percentage of city population included in online unified health files accessible to health care providers. The use of integrated health files can make it easier to provide better health and care services.

- A number of annual medical appointments made over distance per 100,000 population. Remote medical appointments provide an indispensable alternative to inperson medical appointments that refer to a patient's visit to a health care facility.

6) Recreation

Percentage of public recreational services that can be ordered online. Online recreation bookings can provide increased accessibility and awareness for the public, as well as a source of data for public recreation participation.

7) Security

Percentage of city area covered by digital surveillance cameras. The existence of surveillance cameras can prevent crimes and other violations.

8) Sports and culture

- Online bookings for cultural facilities per 100,000 inhabitants. Cultural facilities and cultural/sporting events have an important role to play in connecting people and in building a more cohesive and open society.

- Percentage of urban cultural records that have been digitized. Digital preservation of cultural records is a form of digital preservation to ensure cultural artifacts are preserved for future users.

- Some public library books and e-book titles per 100,000 population. The availability of e-books indicates the degree of digitization of the library as well as the ease of access to books via the library website.

9) Telecommunication

- Percentage of urban population with access to broadband (broadband) with adequate speed. Broadband (broadband) with adequate speed helps people to access a wider range of information.

- Percentage of city area under white zone / dead spots / not covered by telecommunication connectivity. White zones and dead spots are barriers to communication and access to basic services.

- Percentage of city area covered by Internet connectivity provided by the city. A publicly accessible internet could allow cities to passively track users for future planning purposes.

10) Urban planning

- Percentage of building permits submitted via electronic delivery systems. Submitting a building permit application electronically may help speed up the permit building process.

- Percentage of urban population living in moderate to high population density. Higher population densities can contribute to smart growth.

11) Water

- Percentage of city water distribution networks monitored by intelligent water systems. A smart water system is an integrated approach to managing water use in cities. The intelligent water system consists of a network of sensors and meters which provide information about water consumption and water leaks in the distribution network.

- Percentage of buildings in urban areas with smart water meters. The smart water meter can record and display realtime water consumption. 


\section{CONCLUSION}

Based on the analysis results of 19 sectors contained in SNI ISO 37122 , 11 sectors have roles in limiting the spread of the Covid19 pandemic. The selection of this sector is based on the score obtained from each sector which is the result of expert judgment. These sectors are the economy, environment, and climate change, finance, governance, health, recreation, safety, sport and culture, telecommunication, urban planning, and water. From these 11 sectors, 21 indicators can limit the spread of a pandemic in Indonesia. This research is still preliminary, further verification is needed with the growth rate of Covid-19 patients for each region that has implemented indicators in the selected sector.

\section{ACKNOWLEDGMENT}

The author would like to thank the Center for Research and Human Resources Development of the National Standardization Agency of Indonesia for financing the publication of this paper.

\section{REFERENCES}

Abusaada, H., \& Elshater, A., 2020. COVID-19 Challenge, Information Technologies, and Smart Cities: Considerations for Well-Being. International Journal of Community Well-Being, 3(3), 417-424. https://doi.org/10.1007/s42413-020-00068-5

Awaluddin, M., 2016. Katalog smart city solution. Retrieved from Telkom Solution website: www.telkomsolution.com/ themes/v2/catalogue/Katalog Smart Cit y v4.pdf

Boyne, G., R., A., \& Tom, E., 2010. Public Service Improvement: Theories and Evidence. New York: Oxford Universty Press.

Costa, D. G., Vasques, F., Portugal, P., \& Aguiar, A., 2020. A distributed multi-tier emergency alerting system exploiting sensors-based event detection to support smart city applications. Sensors (Switzerland), 20(1). https://doi.org/10.3390/s20010170

Enceng, \& Hidayat, A., 2016. Peningkatan Layanan Publik Melalui. Jurnal Administrasi Pembangunan, 4, 87-96.

Giffinger, R., Fertner, C., \& Kramar, H., 2007. City Ranking of European Medium SizedCities. Vienna University of Technology \& Delft University of Technology.

Goldsmith, S., \& Crawford, S., 2014. The Responsive City: Engaging Communities Through Data-Smart Governance. Jossey-Bass.

James, P., Das, R., Jalosinska, A., \& Smith, L., 2020. Smart cities and a data-driven response to COVID-19. Dialogues in Human Geography, 10(2), 255-259. https://doi.org/10.1177/ 2043820620934211

Kunzmann, K. R., 2020. Smart Cities After Covid-19: Ten Narratives. Disp - The Planning Review, 56(2), 20-31. https://doi.org/10.1080/02513625.2020.1794120

Kurnadi, M., 2015. Penggunaan Internet of Things (IoT) untuk pengembangan Smart City di Indonesia. Retrieved from techinasia.com website: https://id.techinasia.com/penggunaaniot-untuk-pengembangan-smart-city-di-indonesia

Kylili, A., Afxentiou, N., Georgiou, L., Panteli, C., Morsink-
Georgalli, P. Z., Panayidou, A., ... Fokaides, P. A., 2020. The role of Remote Working in smart cities: lessons learnt from COVID-19 pandemic. Energy Sources, Part A: Recovery, Utilization and Environmental Effects, $00(00), 1-16$. https://doi.org/10.1080/15567036.2020.1831108

Lazuardi, A. L., 2015. Manajemen Strategis Inovasi dan Teknologi, terjemahan dari Strategic Management of Technological Innovation,. Yogyakarta: Penerbit Pustaka Pelajar.

Mujiyono, Angkasa, M. P., \& Rismawati, S. D., 2016. Kesiapan Kota Pekalongan Menuju Smart City. Jurnal Litbang Kota Pekalongan, 11, 107-116.

Nijkamp, P., 2008. E pluribus unum. VU University Amsterdam.

Nugraha, M., 2014. Manajemen Strategis Pemerintahan (Ketiga). Jakarta: Penerbit Universitas Terbuka.

Nurmandi, A., 2006. Manajemen Perkotaan: Aktor, Organisasi, Pengelolaan Daerah Perkotaan dan Metropolitan di Indonesia. Yogyakarta: Sinergi Publishing.

Onoda, H., 2020. Onoda, Hiroshi. "Smart approaches to waste management for post-COVID-19 smart cities in Japan. IET Smart Cities, 2(2), 89-94.

Plimbi, E., 2014. Smart City, Konsep Kota Cerdas Sebagai Alternatif Penyelesaian Masalah Perkotaan di Indonesia. Retrieved from plimbi.com website: http://www.plimbi.com/ news/158601/smart-city-konsep-kota-cerdas

Sonn, J. W., Kang, M., \& Choi, Y., 2020. Smart city technologies for pandemic control without lockdown. International Journal of Urban Sciences, O(0), 1-3. https://doi.org/10.1080/12265934.2020.1764207

Syahbudin, 2016. Analisis penerapan smart city dan internet of thin gs ( iot ) di indonesia. ResearchGate, (1), 1-5. Retrieved fromhttps://www.academia.edu/15371881/ANALISIS_PENER APAN_SMART_CITY_DAN_INTERNET_OF_THINGS_IOT _DI_INDONESIA

Utomo, C. E. W., \& Hariadi, M., 2016. Strategi Pembangunan Smart City dan Tantangannya bagi Masyarakat Kota. Jurnal Strategi Dan Bisnis, 4(2), 159-176. 